\title{
Pituitary response to GnRH and ovariectomy in Booroola-Awassi and Awassi ewe lambs
}

\author{
R. Braw-Tal and E. Gootwine \\ Institute of Animal Science, A.R.O., The Volcani Center, Bet Dagan 50250, Israel
}

\begin{abstract}
Summary. Booroola-Awassi ewe lambs were heterozygous $(F+)$ for a major gene $F$, influencing their ovulation rate, while Awassi lambs were non-carriers $(++)$. Basal plasma FSH concentration (mean \pm s.e.m.) in Booroola-Awassi ewe lambs at 4 weeks of age was significantly higher than in Awassi lambs of the same age (5.06 \pm 0.60 and $2.04 \pm 0.32 \mathrm{ng} / \mathrm{ml}$ respectively; $P<0.001$ ). After GnRH administration, FSH increased from $3.89 \pm 1 \cdot 10$ to $10.58 \pm 1.30 \mathrm{ng} / \mathrm{ml}$ in Booroola-Awassi $(\mathrm{N}=6)$ and from $1.87 \pm 0.29$ to $4.64 \pm 0.33 \mathrm{ng} / \mathrm{ml}$ in Awassi $(\mathrm{N}=6)$ ewe lambs $(P<0.05)$. Ovariectomy caused an increase in plasma FSH in Booroola-Awassi $(\mathrm{N}=4)$ and Awassi $(\mathrm{N}=4)$ ewe lambs. At 1 week after ovariectomy plasma FSH increased from $5.96 \pm 1.02$ to $7.06 \pm 1.05 \mathrm{ng} / \mathrm{ml}$ in $\mathrm{F}+$ and from $1.67 \pm 1.06$ to $5.21 \pm 0.66 \mathrm{ng} / \mathrm{ml}$ in ++ ewe lambs, suggesting a stronger negative feed-back effect exerted by the ovaries of Awassi lambs. At 15 weeks after ovariectomy FSH values were similar in BooroolaAwassi $(18.28 \pm 1.96 \mathrm{ng} / \mathrm{ml})$ and Awassi $(16.07 \pm 0.70 \mathrm{ng} / \mathrm{ml})$ lambs. Although the overall pattern of pituitary response to ovariectomy was similar in the $\mathrm{F}+$ and ++ ewe lambs, Booroola-Awassi lambs had small ovaries (132.5 $\pm 24.9 \mathrm{mg})$ and follicular development did not proceed beyond the preantral stage in $3 / 4$ animals, and Awassi lambs had large ovaries $(600.0 \pm 233.9 \mathrm{mg})(P<0.05)$ with many preantral and antral follicles.

The present results suggest that (1) the elevated plasma FSH concentration between 3 and 6 weeks of age in Booroola-Awassi compared to Awassi ewe lambs might be due to (a) greater responsiveness of the $F+$ pituitary to $\mathrm{GnRH}$ and (b) reduced ovarian suppression of FSH release and (2) the ovaries of Booroola-Awassi lambs, although lacking antral follicles, secrete a factor that controls FSH values. We suggest that differences between the two genotypes can be attributed to the $F$ gene or to other minor genes that came from the Booroola-Merino sires used to create the Booroola-Awassi progeny.
\end{abstract}

Keywords: sheep; pituitary; ovary; genotype

\section{Introduction}

The Booroola Merino is one of the most prolific sheep breeds known (see review by Bindon, 1984). The exceptional prolificacy of the Booroola has been attributed to a major putative gene, the fecundity gene (F), which influences their ovulation rate (Piper \& Bindon, 1982; Davis et al., 1982). The reproductive physiology of Booroola-Merino and Booroola-Romney ewes has been extensively studied during recent years (Bindon et al., 1985a; McNatty \& Henderson, 1987). It has been shown that Booroola ewe lambs are characterized by elevated basal plasma FSH concentration between 3 and 6 weeks of age (Findlay \& Bindon, 1976; Bindon et al., 1985b) and it has been suggested that differences in ovarian feed-back regulation of FSH, which is known to be operative by this age, is responsible for this phenomenon (Tassell et al., 1983). 
The aim of the present study was to characterize ovarian-pituitary relationships and to determine pituitary response to $\mathrm{GnRH}$ in young ewe lambs with and without the fecundity gene.

\section{Materials and Methods}

Animals. The 21 Awassi and 14 Booroola-Awassi ewe lambs, used in this study, were born in autumn 1986. The Booroola-Awassi lambs were the progeny of 3 Booroola Merino rams, homozygous for gene $F(F F)$, obtained from the Invermay Agricultural Research Centre, New Zealand, and Awassi ewes from Ein Harod, Israel, flock. Hence Booroola-Awassi ewe lambs were heterozygous for gene $F(F+)$ while Awassi lambs were non-carriers $(++)$. The live body weights of the ewe lambs (mean \pm s.e.m.) were $4.30 \pm 0.12$ and $4.07 \pm 0.22 \mathrm{~kg}$ at birth and $12.69 \pm 0.45$ and $10.82 \pm 0.43 \mathrm{~kg}$ at $l$ month of age for Awassi and Booroola-Awassi respectively. Until weaning, at about 4 weeks of age, ewe lambs were kept in an artificial rearing unit; thereafter they received concentrated food, chopped hay and water ad libitum.

Blood sampling. Blood samples were taken at 1 week (mean \pm s.d., $7 \pm 2$ days), $2(15 \pm 2), 3(21 \pm 2), 4(28 \pm 2)$, $5(35 \pm 2), 6(43 \pm 2), 9(66 \pm 4)$ and $15(104 \pm 6)$ weeks of age from 17 Awassi and 10 Booroola-Awassi ewe lambs. In addition, 3 weekly blood samples were taken before the operation from animals ovariectomized at 30-46 days (see below). About 5-10 ml jugular blood were collected at each occasion into a heparinized, evacuated tube. Blood sampling after GnRH treatment and ovariectomy is described below. Blood samples were centrifuged at $2000 \mathrm{~g}$ for $20 \mathrm{~min}$ and plasma was frozen until assayed. All samples collected from one ewe lamb were run in one radioimmunoassay.

GnRH treatment. From animals used for weekly blood sampling 6 Awassi and 6 Booroola-Awassi ewe lambs aged $40-45$ days were randomly chosen and $30 \mu \mathrm{g}$ of a synthetic $\mathrm{GnRH}$ analogue (Fertagyl: Intervet, Cambridge, UK) were administered intravenously twice $80 \mathrm{~min}$ apart. The experimental design was based on a previous report that the $\mathrm{LH}$ response to this $\mathrm{GnRH}$ analogue is maximal after two consecutive administrations (Gur-Arie et al., 1986). Blood samples were collected as follows: 40 and $20 \mathrm{~min}$ before the $\mathrm{GnRH}$ injection, 20,40 and $60 \mathrm{~min}$ after the first $\mathrm{GnRH}$ injection, and 20, 40,60 and $80 \mathrm{~min}$ after the second $\mathrm{GnRH}$ injection. On each occasion $2 \mathrm{ml}$ blood were collected using a 3 -ml syringe with 20 -gauge, $2 \cdot 2 \mathrm{~cm}$ needle, washed with heparin solution after each collection. Plasma was obtained and stored as described above. All samples collected in this experiment were run in one radioimmunoassay.

Ovariectomy. Four Awassi and 4 Booroola-Awassi aged 30-46 days, live body weights (mean \pm s.e.m.) of $13.2 \pm 0.27$ and $13.9 \pm 0.37 \mathrm{~kg}$ and growth rates (mean \pm s.e.m.) of $0.269 \pm 0.017$ and $0.260 \pm 0.019 \mathrm{~kg} /$ day, respectively, were ovariectomized under general anaesthesia induced by ketamine (Vetalar: Bayer, Munich, FRG). Ovaries were weighed, fixed in Bouin's solution and processed for histological examination (see below). As controls, 4 Awassi and 4 Booroola-Awassi lambs of the same age, body weights of $17.8 \pm 1.35$ and $13.3 \pm 0.49 \mathrm{~kg}$ and growth rates of $0.335 \pm 0.036$ and $0.218 \pm 0.016 \mathrm{~kg} /$ day, respectively, were sham-operated. Blood samples were taken once a week from the 1st week before the operation to the 5th week after the operation and again at the age of about 140 days. On each occasion, 11 blood samples $(2 \mathrm{ml}$ each) were collected from jugular vein every 20 min using a $3 \mathrm{ml}$ syringe with 20 -gauge, $2 \cdot 2 \mathrm{~cm}$ needle. Plasma was obtained and stored as described above. In 6 randomly chosen animals plasma FSH was determined in all 11 samples collected on one day. As the coefficient of variation between samples from the same ewe lamb was $<15 \%$ we decided to use plasma from the 1st, 5 th and 10 th collections only for FSH determinations. The values for FSH concentrations were then averaged to provide a single value for each ewe lamb. All samples from one particular day were run in one radioimmunoassay.

FSH assay. Plasma FSH concentration was measured by an homologous radioimmunoassay using kit supplied by NIAMDD, Bethesda, Maryland, USA. The standard preparation was NIAMDD-oFSH-RP-1. For iodination highly purified NIAMDD-oFSH-I-1 $(75 \times$ NIH-FSH-S-1) was used. Cross-reactions of rabbit anti-ovine FSH (NIAMDDanti-oFSH-1) with other ovine pituitary hormones were: $\mathrm{LH}(2.4 \times \mathrm{NIH}-\mathrm{LH}-\mathrm{S}-1)<0.1 \%$, prolactin $<0.0003 \%, \mathrm{GH}$ $<0.02 \%$. The within- and between-assay coefficients of variation were $3 \%$ and $10 \%$, respectively. The limit of detection was $0.3 \mathrm{ng} / \mathrm{ml}$ plasma. Values are expressed in $\mathrm{ng}$ NIAMDD-oFSH-RP-1/ml plasma.

Histological procedures and follicle classification. The Bouin-fixed ovaries were embedded in paraffin wax and serially sectioned at a thickness of $5 \mu \mathrm{m}$. One section out of 11 was mounted and stained with haematoxylin-eosin. Preantral follicles with 2 or more layers of granulosa cells were counted using the nucleus of the oocyte as a marker. Antral follicles were counted using the oocyte as a marker. The mean diameter of each follicle was measured and follicles were then classified in 5 size classes, according to Driancourt \& Mariana (1982). Follicles with 5 or more pycnotic nuclei in the granulosa layer or follicle fluid of the section studied were classified as atretic. Follicles in late atresia, in which the oocyte could not be found or in which connective tissue had invaded the follicular cavity, were not considered in this study.

Statistical analysis. Statistical differences between groups were calculated using Student's $t$ test and one-way analysis of variance. 


\section{Results}

\section{Basal plasma FSH concentrations}

Mean basal plasma FSH concentrations as a function of age for Awassi and Booroola-Awassi ewe lambs are shown in Fig. 1. In all Awassi ewe lambs studied basal FSH concentration was low $(<3 \mathrm{ng} / \mathrm{ml})$ during first 2 months of age. In 7 Awassi lambs FSH remained low until the end of the period of study, while in 10 animals a 2-3-fold increase was detected at about 2 months of age. There were no significant phenotypic differences between these two groups of Awassi lambs. Booroola-Awassi ewe lambs had a markedly different pattern of basal FSH secretion. They all had elevated basal FSH concentrations between 3 and 6 weeks of age which decreased thereafter. The most significant difference between the genotypes was observed at 4 weeks of age when concentrations of FSH (mean \pm s.e.m.) were $2.04 \pm 0.32$ and $5.06 \pm 0.60 \mathrm{ng} / \mathrm{ml}(P<0.001)$ for Awassi and Booroola-Awassi ewe lambs respectively. At 15 weeks of age, however, plasma FSH concentration in Awassi lambs $(3.87 \pm 0.56 \mathrm{ng} / \mathrm{ml})$ was higher than in Booroola-Awassi lambs $(1 \cdot 74 \pm 0 \cdot 10 \mathrm{ng} / \mathrm{ml})(P<0.05)$.

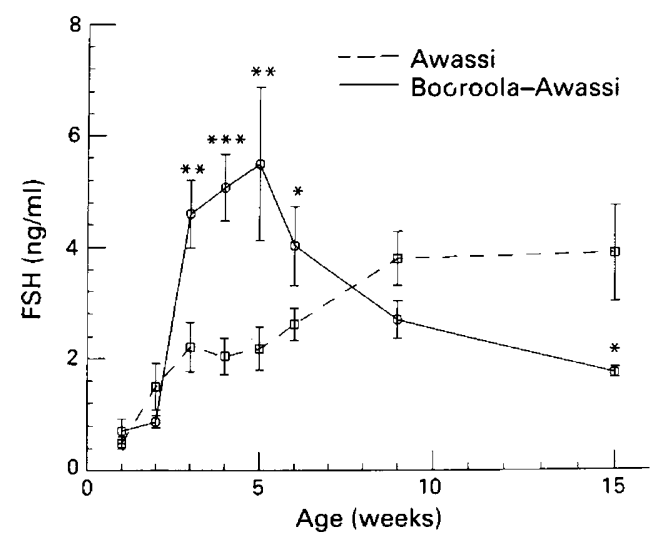

Fig. 1. Basal plasma FSH concentrations in Awassi and Booroola-Awassi ewe lambs. Each value represents the mean \pm s.e.m. of 9-16 (Awassi) or 6-14 (Booroola-Awassi) determinations. Significant difference between the genotypes is indicated: ${ }^{*} P<0.05,{ }^{* *} P<0.01$, ${ }^{* * *} P<0.001$.

\section{Effect of GnRH on plasma FSH concentration}

GnRH administration resulted in increase in plasma FSH within $20-40 \mathrm{~min}$ in ewe lambs of both genotypes (Fig. 2), although Booroola-Awassi lambs showed a significantly greater response than did Awassi lambs. The increase in FSH concentration above the basal value (maximal FSH concentration after GnRH injection minus mean of FSH concentrations in 2 samples taken before GnRH treatment) was 2-fold higher in Booroola-Awassi than in Awassi ewe lambs (Table 1). The second injection of $\mathrm{GnRH}$ to the same ewe lamb resulted in a higher response, compared to the first injection, but the difference was not significant.

\section{Effect of ovariectomy on plasma FSH concentration}

Ovariectomy caused an increase in plasma FSH concentration in ewe lambs of both genotypes, although in Awassi lambs the increase was more rapid during 1st week after the operation than in 


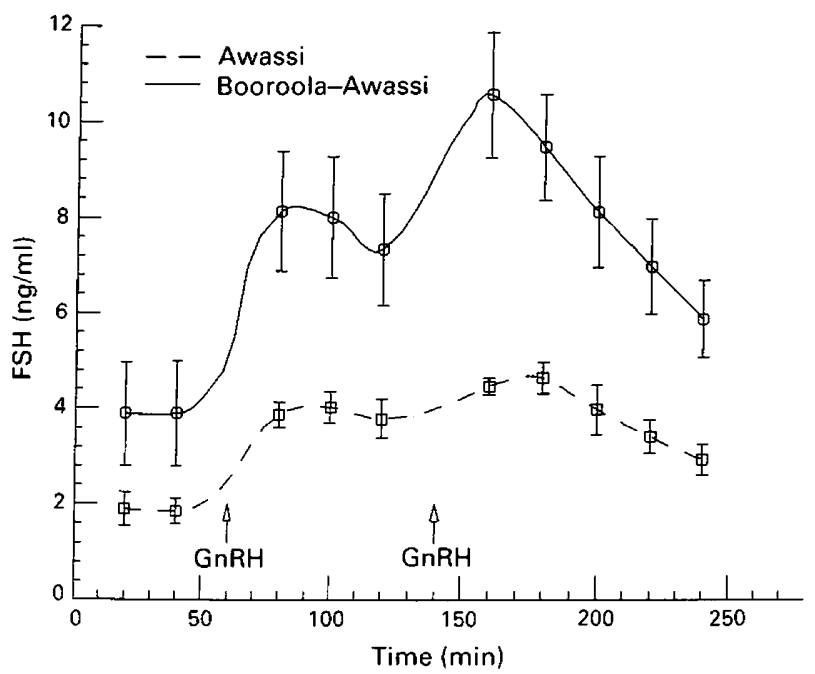

Fig. 2. Plasma FSH response to GnRH administration in 40-45-day-old Awassi and BooroolaAwassi lambs. GnRH $(30 \mu \mathrm{g})$ was injected as indicated. Each value represents the mean \pm s.e.m. of 6 determinations. Significant differences $(P<0.05)$ between genotypes existed for all values after GnRH treatment.

Table 1. Effect of GnRH administration on plasma FSH concentration in 40-45-day-old Awassi and Booroola-Awassi ewe lambs

\begin{tabular}{lcccc}
\hline \multirow{2}{*}{ Genotype } & $\begin{array}{c}\text { No. of } \\
\text { lambs }\end{array}$ & $\begin{array}{c}\text { Basal FSH } \dagger \\
(\mathrm{ng} / \mathrm{ml})\end{array}$ & \multicolumn{3}{c}{ 1st injection } & 2nd injection \\
\hline Awassi & 6 & $1.87 \pm 0.29$ & $2.21 \pm 0.22$ & $3.07 \pm 0.27$ \\
Booroola-Awassi & 6 & $3.89 \pm 1 \cdot 10$ & $4.38 \pm 0.74^{*}$ & $6.69 \pm 1 \cdot 16^{*}$ \\
\hline
\end{tabular}

† Mean \pm s.e.m. of two samples taken before GnRH treatment.

$\$$ Maximal value \pm s.e.m. after GnRH injection minus mean of 2 samples taken before treatment.

${ }^{*} P<0.05$ compared to value for Awassi lambs.

Booroola-Awassi lambs (Table 2). The overall pattern of increase in hormone concentration was, however, similar in lambs of both genotypes.

\section{Ovarian morphology}

Ovaries of Awassi ewe lambs were large and the weight of paired ovaries (mean \pm s.e.m.) was $600 \cdot 0 \pm 233.9 \mathrm{mg}$. They contained many preantral and antral follicles (Table 3, Fig. 3a). Ovaries of Booroola-Awassi were significantly smaller and weighed $132.5 \pm 24.9 \mathrm{mg}(P<0.05)$. Only one ewe lamb had ovaries with antral follicles. The ovaries of the other 3 ewe lambs studied had only preantral follicles (Table 3, Fig. 3b).

\section{Discussion}

The present study shows a striking difference in the ovarian morphology between BooroolaAwassi and Awassi ewe lambs. The 30-46-day-old Booroola-Awassi lambs had small ovaries with 


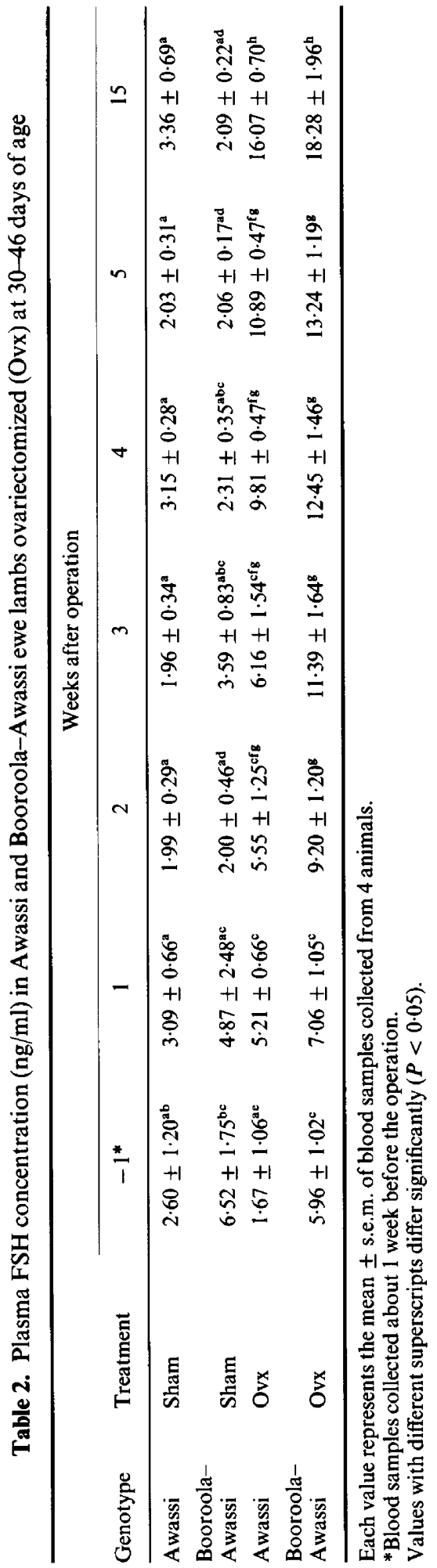


Table 3. Number of follicles and largest follicle diameter in the ovaries of 30-46-day-old Awassi and Booroola-Awassi ewe lambs

\begin{tabular}{|c|c|c|c|c|c|c|c|}
\hline & \multirow[b]{2}{*}{$\begin{array}{l}\text { Preantral } \\
\text { follicles }\end{array}$} & \multicolumn{4}{|c|}{ Diam. of antral follicles (mm)* } & \multirow[b]{2}{*}{$\begin{array}{c}\text { Total } \\
(\% \text { non-atretic }) \dagger\end{array}$} & \multirow{2}{*}{$\begin{array}{l}\text { Largest } \\
\text { follicle diam } \\
\quad(\mathrm{mm})\end{array}$} \\
\hline & & $\begin{array}{c}0 \cdot 20- \\
0 \cdot 32\end{array}$ & $\begin{array}{c}0.33- \\
0.50\end{array}$ & $\begin{array}{c}0.51- \\
0 \cdot 80\end{array}$ & $\begin{array}{c}0 \cdot 81- \\
2 \cdot 00\end{array}$ & & \\
\hline \multicolumn{8}{|l|}{ Awassi } \\
\hline 1857 & 59 & 125 & 58 & 84 & 69 & $336 \quad(81 \cdot 2)$ & $1 \cdot 14$ \\
\hline 2447 & 44 & 0 & 0 & 2 & I & $3(100 \cdot 0)$ & 0.83 \\
\hline 2213 & 42 & 5 & 6 & 10 & 17 & $33(27 \cdot 3)$ & 0.91 \\
\hline 2387 & 127 & 0 & 30 & 53 & 33 & $116(72 \cdot 4)$ & $1 \cdot 20$ \\
\hline \multicolumn{8}{|c|}{ Booroola-Awassi } \\
\hline 2509 & 128 & 1 & 4 & 4 & 4 & $13 \quad(77 \cdot 0)$ & 1.91 \\
\hline 2681 & 13 & 0 & 0 & 0 & 0 & 0 & 0 \\
\hline 2397 & 25 & 0 & 0 & 0 & 0 & 0 & 0 \\
\hline 2068 & 16 & 0 & 0 & 0 & 0 & 0 & 0 \\
\hline
\end{tabular}

*Antral follicles were classified according to Driancourt \& Mariana (1982).

†Follicles with 5 or more pycnotic nuclei were considered atretic.

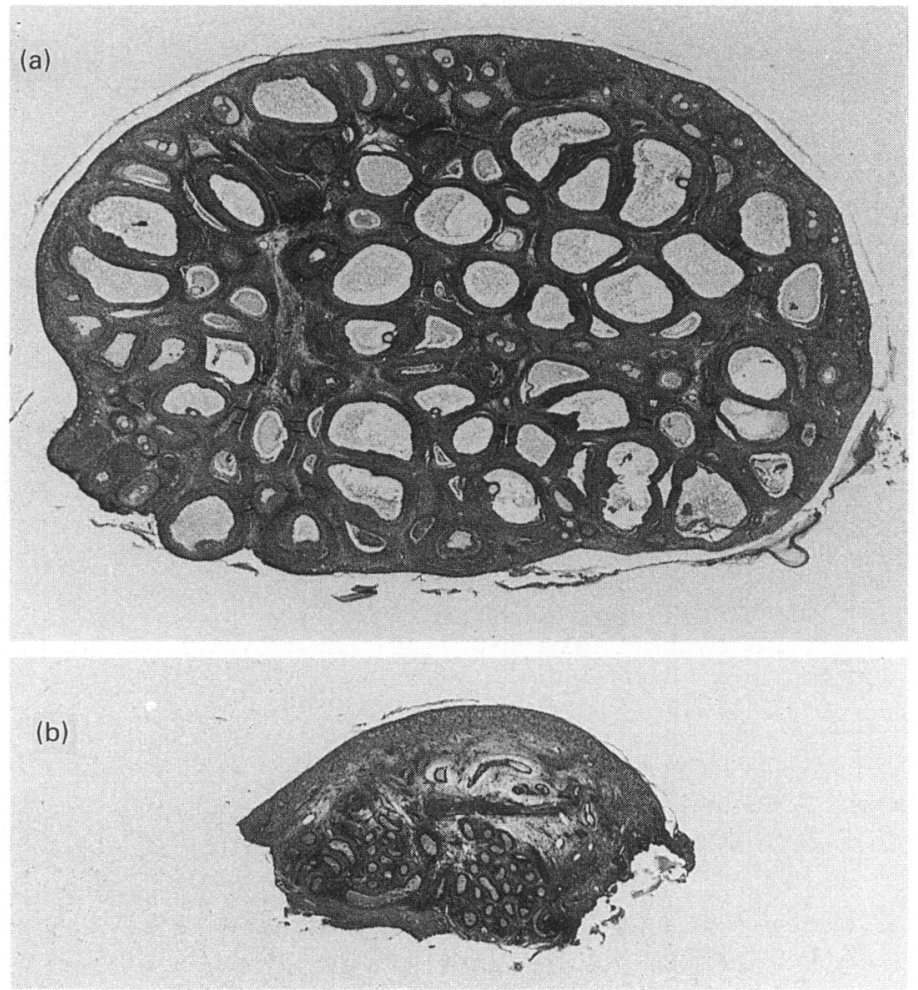

Fig. 3. Histological sections of the ovary of (a) a 30-day-old Awassi ewe lamb (No. 1857) and (b) a 33-day-old Booroola-Awassi ewe lamb (No. 2397). H \& E, $\times 8$. 
follicular development that rarely proceeded beyond the preantral stage, while Awassi lambs of the same age contained large ovaries with many preantral and antral follicles (Table 3; Fig. 3). The question arises as to why Booroola-Awassi ewe lambs have impaired follicular development compared to Awassi lambs. Although we studied ewe lambs of two different genotypes, their growth rates were very similar (see 'Materials \& Methods'), and so it seems unlikely that it had an effect on ovarian development. Genes that came from the Merino breed used to create Booroola-Awassi progeny might have an effect on follicular development. However, Tassell et al. (1978) reported that 4-week-old Merino lambs contained antral follicles $\geq 1 \mathrm{~mm}$ in diameter. On the other hand, newborn Booroola-Merino lambs had fewer antral follicles than did control Merino lambs (Tassell et al., 1983) and 1-month-old Booroola-Assaf ewe lambs had smaller ovaries and fewer antral follicles than did Assaf lambs (Braw-Tal et al., 1988). Our results suggest that the structure of the ovary of the lamb might be influenced by the $\mathrm{F}$ gene, although the possibility that other components of the Booroola genotype may be also responsible cannot be excluded.

In our study, ovariectomy of 4-6-week-old Awassi ewe lambs resulted in a rapid increase in plasma FSH concentration (Table 2). Despite impaired follicular development and lack of antral follicles, ovariectomy of Booroola-Awassi ewe lambs also resulted in increased plasma FSH concentration (Table 2). Hence ovarian feed-back regulation of FSH release is operative in ++ as well as F + ewe lambs of 4-6 weeks of age although the pituitary of Booroola-Awassi lambs was only partly suppressed by the ovaries since their response to ovariectomy was slower than that of Awassi. The question arises as to what are the ovarian component(s) responsible for the control of plasma FSH concentration in Booroola ewe lambs? It is well known that FSH secretion is modulated by gonadal steroids as well as inhibin and other non-steroidal substances of gonadal origin (Goodman et al., 1981; Martin et al., 1986; Ying, 1988). Although inhibin is secreted mainly by granulosa cells of antral follicles (Henderson \& Franchimont, 1981; Findlay et al., 1986), the possibility that theca and/or interstitial cells might also be a source of inhibin or other related factors regulating FSH secretion cannot be excluded. Transforming growth factor (TGF- $\beta$ ), a peptide homologous to inhibin (Ling et al., 1986), was in fact reported to be secreted by bovine and rat theca cells (Skinner et al., 1987). Whether FSH values in young Booroola-Awassi ewe lambs are controlled by such factors and whether they are linked to the $F$ gene remains an open and intriguing issue.

Our present results demonstrate that FSH release in response to $\mathrm{GnRH}$ administration, at 1 month of age, is significantly higher in $\mathrm{F}+$ than in ++ ewe lambs (Table 1, Fig. 2). Bindon et al. (1985b) reported an increase in FSH concentration following GnRH treatment at 100 but not at 30 days. This discrepancy might be due to breed and/or experimental design differences. The higher response to GnRH might be due to greater FSH content in the pituitary of Booroola than in control ewe lambs, as reported by Robertson et al. (1984) and McNatty et al. (1987), or to a higher sensitivity of the pituitary of Booroola-Awassi than Awassi lambs to GnRH.

In the present study Booroola-Awassi ewe lambs had elevated plasma FSH concentration between 3 and 6 weeks of age, similar to that observed in Booroola-Merino lambs (Findlay \& Bindon, 1976; Bindon et al., 1985b). Our results suggest that higher responsiveness of the Booroola-Awassi lamb pituitary to GnRH and reduced suppression of FSH release by their gonads leads to elevated plasma FSH concentration in these animals. Whether it can be attributed to the $\mathrm{F}$ gene or other components of the Booroola genotype remains to be established.

We thank Dr J. Allison, Invermay Agricultural Research Centre, New Zealand, for supplying Booroola rams; NIAMDD for generous provision of preparations for FSH RIA; Dr N. Dekel for reading the manuscript and helpful suggestions; Dr A. Bor for the operations; A. Zenou for technical assistance; and I. Dimerman for supervision and care of the animals. This study was supported by the Israel Academy of Sciences and BARD. 


\section{References}

Bindon, B.M. (1984) Reproductive biology of the Booroola Merino sheep. Aust. J. biol. Sci. 37, 163-189.

Bindon, B.M., Piper, L.R., Cummins, L.J., O'Shea, J., Hillard, M.A., Findlay, J.K. \& Robertson, D.M. (1985a) Reproductive endocrinology of prolific sheep: studies on the Booroola Merino. In Genetics of Reproduction in Sheep, pp. 217-235. Eds R. B. Land \& D. W. Robinson. Butterworths, London.

Bindon, B.M., Findlay, J.K. \& Piper, L.R. (1985b) Plasma FSH and LH in prepubertal Booroola ewe lambs. Aust. J. biol. Sci. 38, 215-220.

Braw-Tal, R., Bor, A. \& Gootwine, E. (1988) Plasma FSH and ovarian follicular population in prepubertal Booroola-Awassi and Booroola-Assaf ewe lambs. Proc. 3rd World Congress on Sheep and Beef Cattle Breeding, pp. 661-663. INRA, Paris.

Davis, G.H., Montgomery, G.W., Allison, A.J., Kelly, R.W. \& Bray, A.R. (1982) Segregation of a major gene influencing fecundity of progeny of Booroola sheep in New Zealand. N.Z. Jl agric. Res. 25, 525-529.

Driancourt, M.A. \& Mariana, J.C. (1982) Short- and long-term effects of $\mathrm{X}$ irradiation on ovarian follicular populations in the ewe. Reprod. Nutr. Develop. 22 , 813-823.

Findlay, J.K. \& Bindon, B.M. (1976) Plasma FSH in Merino lambs selected for fecundity. J. Reprod. Fert. 46, 515-516.

Findlay, J.K., Tsonis, C.G., Staples, L.D. \& Cahill, R.N.P. (1986) Inhibin secretion by the sheep ovary. $J$. Reprod. Fert. 76, 751-761.

Goodman, R.L., Pickover, S.M. \& Karsch, F.J. (1981) Ovarian feedback control of follicle-stimulating hormone in the ewe: evidence for selective suppression. Endocrinology 108, 772-777.

Gur-Arie, E., Rosenberg, M., Hillel, J., Folman, Y. \& Eyal, E. (1986) Repeatability of the plasma luteinizing-hormone response to two consecutive injections of gonadotropin-releasing hormone to prepubertal ewe lambs reared in individual pens. Anim. Reprod. Sci. 12, 85-97.

Henderson, K.M. \& Franchimont, P. (1981) Regulation of inhibin production by bovine ovarian cells. $J$. Reprod. Fert. 63, 431-442.
Ling, N., Ying, S.Y., Ueno, N., Shimasaki, S., Esch, F., Hotta, M. \& Guillemin, R. (1986) Pituitary FSH is released by a heterodimer of the $\beta$-subunits from the two forms of inhibin. Nature, Lond. 321, 779-782.

Martin, G.B., Wallace, J.M., Taylor, P.L., Fraser, H.M., Tsonis, C.G. \& McNeilly, A.S. (1986) The roles of inhibin and gonadotrophin-releasing hormone in the control of gonadotrophin secretion in the ewe. $J$. Endocr. 111, 287-296.

McNatty, K.P. \& Henderson, K.M. (1987) Gonadotrophins, fecundity genes and ovarian follicular function. J. Steroid Biochem. 27, 365-373.

McNatty, K.P., Hudson, N., Henderson, K.M., Gigg, M., Morrison, L., Ball, K. \& Smith, P. (1987) Differences in gonadotrophin concentrations and pituitary responsiveness to $\mathrm{GnRH}$ between Booroola ewes which were homozygous $(\mathrm{FF})$, heterozygous $(\mathrm{F}+)$ and non-carriers $(++)$ of a major gene influencing their ovulation rate. J. Reprod. Fert. 80, 577-588.

Piper, L.R. \& Bindon, B.M. (1982) Genetic segregation for fecundity in Booroola Merino sheep. Proc. World Cong. Sheep \& Cattle Breeding, 1, Technical, pp. 395 400. Eds R. A. Barton \& W. C. Smith. Dunmore Press, Palmerston North.

Robertson, D.M., Ellis, S., Foulds, L.M., Findlay, J.K. \& Bindon, B.M. (1984) Pituitary gonadotrophins in Booroola and control Merino sheep. J. Reprod. Fert. 71, 189-197.

Skinner, M.K., Kessi-Oja, J., Osteen, K.G. \& Moses, H.L. (1987) Ovarian thecal cells produce transforming growth factor $\beta$ which can regulate granulosa cell growth. Endocrinology 121, 786-792.

Tassell, R., Chamley, W.A. \& Kennedy, J.P. (1978) Gonadotrophin levels and ovarian development in the neonatal ewe lamb. Aust. J. biol. Sci. 31, 267-273.

Tassell, R., Kennedy, J.P., Bindon, B.M. \& Piper, L.R. (1983) Ovarian follicles of new-born Merino lambs from genetic lines which differ in fecundity. Aust. $J$. biol. Sci. 36, 351-355.

Ying, S.-Y. (1988) Inhibins, activins and follistatins: gonadal proteins modulating the secretion of folliclestimulating hormone. Endocrine Reviews 9, 267-293.

Received 8 November 1988 